\title{
PELATIHAN PEMBUATAN PUDING SEDOT (PUDOT) JAHE SEBAGAI PENINGKAT IMUNITAS ANAK DISAAT PANDEMIK COVID-19
}

\author{
Siswi Wulandari*, Linda Sri Kusumawati, Huda Rohmawati, Kurnia Novitasari, \\ Yeni Puspita Anggraini \\ Universitas Kadiri \\ *siswiwulandari@unik-kediri.ac.id
}

\begin{abstract}
Coronavirus outbreak that attacks the respiratorytract, which is one of the causesadalahdecreased immunity of the body. Decreased immunity of the body with the same symptoms in people infected with coronavirus including cough, flu, fever and shortness of breath. Providing balanced nutrition is very important for children, as a preventive measure. Increased immunity of the body can be done by consuming drinks from spices, one of which is ginger. Community service is carried out by providing training on 25 to housewives (PKK) and conducted in December 2020 - January 2021 in the village of Sukorame Kediri City. The method used is counseling and demostration of making pudding suction (pudot) ginger while paying attention to health protocol. Residents who participated in this training experienced an increase in knowledge and skills. Obtained the results of $84 \%$ of skilled citizens in the manufacture of ginger pudot.
\end{abstract}

Keywords: pudding suction, ginger, immunity, child, pandemic

\begin{abstract}
Abstrak
Wabah virus corona yang menyerang saluran pernafasan, yang salah satu penyebabnya adalah menurunya imunitas tubuh. Menurunya imunitas tubuh dengan gejala yang juga sama pada orang yang terinfeksi virus corona diantaranya batuk, flu, demam serta sesak nafas. Memberikan nutrisi yang seimbang sangatlah penting bagi anak, sebagai upaya pencegahan. Peningkatan imunitas tubuh bisa dilakukan dengan mengkonsumsi minuman dari rempah-rempah, salah satunya jahe. Pengabdian kepada masyarakat dilaksanakan dengan memberikan pelatihan tentang 25 kepada ibu rumah tangga (PKK) dan dilaksankan pada bulan Desember 2020 - Januari 2021 di kelurahan Sukorame Kota Kediri. Metode yang digunakan adalah penyuluhan dan demostrasi pembuatan pudding sedot (pudot) jahe dengan tetap memperhatikan protocol kesehatan. Warga yang mengikuti pelatihan ini mengalami peningkatan pengetahuan dan keterampilan. Didapatkan hasil $84 \%$ warga terampil dalam pembuatan pudot Jahe.
\end{abstract}

Kata Kunci: pudding sedot, jahe, imunitas, anak, pandemi

Submitted: 2021-05-04 $\quad$ Revised: 2021-07-26 $\quad$ Accepted: 2021-07-31

\section{Pendahuluan}

Wabah virus corona yang menyerang saat ini mempunyai banyak istilah diantaranya Virus corona atau coronavirus, virus ini merupakan bagian dari virus yang menyerang saluran pernafasan. Banyak orang yang terinfeksi virus corona yang salah satu penyebabnya adalah menurunya imunitas tubuh. Menurunya imunitas tubuh dengan gejala yang juga sama pada orang yang terinfeksi virus corona diantaranya batuk, flu, demam serta sesak nafas. Bagi yang telah terinfeksi Virus Corona, tidak pengaobatan dan perawat khusus. Kelompok usia anak rentan terhadap COvid-19. Dibuktikan berdasar hasil temuan IDAI yang melaksanakan upaya deteksi dini kasus Covid-19 pada anak secara mandiri. 
Data yang didapat oleh IDAI sampai dengan bulan Mei 2020 yaitu Jumlah pasien dalam pengawasan (PDP) sebanyak 3324 anak, 129 anak berstatus PDP meninggal, 584 anak terkonfirmasi Covid-19 dan 14 anak meninggal akibat Covid-19. Temuan ini menunjukan bahwa angka kesakitan dan kematian anak akibat Covid-19 masih tergolong tinggi. Beberapa upaya telah dilakukan untuk mencegah penularan virus Corona, diantaranya melakukan perilaku hidup bersih dan sehat, selain itu pada memberikan nutrisi seimbang untuk anak. Memberikan nutrisi yang seimbang sangatlah penting bagi anak, sebagai upaya pencegahan. Beberapa upaya telah dilakukan untuk pencegahan penularan Covid-19 dengan tetap menjaga/meningkatkan imunitas.

Peningkatan imunitas tubuh bisa dilakukan dengan mengkonsumsi minuman dari rempahrempah, salah satunya jahe. Jahe merupakan rempah-rempah yang mudah didapat di Indonesia. Kandungan yang terdapat pada Jahe diantaranya antioksidan dan antiinflamasi. Banyaknya manfaat pada Jahe, namun untuk rasa belum tentu anak suka. Untuk membuat anak mau mengkonsumsi Jahe diperlukan inovasi supaya menarik dan mempunyai rasa yang enak. Inovasi yang mudah dibuat dirumah oleh orang tua dengan membuat Puding Sedot (pudot) Jahe. Puding yang sekarang sedang banyak diminati anak adalah Puding sedot atau biasa disebut dengan Pudot.

Pelatihan pembuatan pudding sedot (pudot) jahe sangat diperlukan mengingat kandungan yang ada di dalam Jahe supaya tetap terjaga. Selain itu juga bisa membuat anak tertarik untuk mengkonsumsinya. Oleh karna itu sangat penting bagi masyarkat mengetahui dan mampu mempraktekan pembuatan pudding sedot jahe

\section{Metode}

Pengabdian kepada masyarakat dilaksanakan dengan memberikan pelatihan tentang 25 kepada ibu rumah tangga (PKK) dan dilaksankan pada bulan Desember 2020 - Januari 2021 di kelurahan Sukorame Kota Kediri. Metode yang digunakan adalah penyuluhan dan demostrasi pembuatan pudding sedot (pudot) jahe dengan tetap memperhatikan protocol kesehatan. Kegiatan dalam pengabdian masyarakat dengan SAP pelatihan guna meningkatan pengatahuan tentang manfaat jahe dan keterampilan pengolahan Jahe menjadi pudding sedot (pudot) yang disukai anak.

Dokumentasi dilakukan degan memberikan absensi, pretest-posttest tenatng manfaat jahe, foto hasil pudding sedot. Evaluasi kegiatan dengan menggunakan posttes dan penilaian rasa pudot jahe.

\section{Hasil dan Pembahasan}

Jumlah responden dalam kegiatan ini ada 25 ibu rumah tangga yang dibagi menjadi beberapa kelompok. Hasil dari kegiatan pengabdian kepada masyarakat adalah sebagai berikut:

Tabel 1. Pengetahuan tentang Jahe sebelum dan sesudah penyuluhan

\begin{tabular}{lcccc}
\hline \multirow{2}{*}{ Kategori } & \multicolumn{2}{c}{$\begin{array}{c}\text { Pengetahuan tentang Jahe sebelum } \\
\text { Penyuluhan }\end{array}$} & \multicolumn{2}{c}{$\begin{array}{c}\text { Pengetahuan tentang Jahe setelah } \\
\text { Penyuluhan }\end{array}$} \\
\cline { 2 - 5 } & $\mathrm{F}$ & $\%$ & $\mathrm{~F}$ & $\%$ \\
\hline Kurang & 4 & 16 & 0 & 0 \\
Cukup & 16 & 64 & 8 & 32 \\
Baik & 5 & 20 & 17 & 68 \\
Total & 25 & 100 & 25 & 100 \\
\hline
\end{tabular}

Berdasar table 1 dapat diketahui 5 responden mempunyai pengetahuan baik sebelum penyuluhan dan 17 reponden mempunyai pengetahuan baik setelah penyuluhan. Jahe adalah 
tanaman yang mudah didapat di sekitar rumah dan sudah banyak produk instan yang bisa dengan mudah didapat. Pengetahuan tentang kandungan, manfaat dan cara pengolahan Jahe sangat diperlukan. Pengetahuan yang meningkat akan menarik minat masyarakat untuk menyediakan di rumah sebagai salah satu rempah-rempah banyak mengandung antiinflamasi dan antiksidan.

Tabel 2. Keterampilan pembuatan pudot sebelum dan sesudah demonstrasi pembuatan pudot

\begin{tabular}{lcccc}
\hline \multirow{2}{*}{ Kategori } & \multicolumn{2}{c}{ Keterampilan sebelum demonstrasi } & \multicolumn{2}{c}{ Keterampilan setelah demonstrasi } \\
\cline { 2 - 5 } & $\mathrm{F}$ & $\%$ & $\mathrm{~F}$ & $\%$ \\
\hline Kurang & 6 & 24 & 0 & 0 \\
Cukup & 15 & 60 & 4 & 16 \\
Baik & 4 & 16 & 21 & 84 \\
Total & 25 & 100 & 25 & 100 \\
\hline
\end{tabular}

Berdasar table 2 dapat diketahui 4 responden mempunyai keterampilan baik sebelum demonstrasi dan 21 Responden mempunyai keterampilan baik setelah demonstrasi. Keterampilan pengolahan Jahe yang baik akan memberikan manfaat dalam meningkatkan imunitas terutama pada anak di masa pandemik. Pengolahan Jahe yang menarik akan meningkatkan minat anak dalam mengknsumsinya. Peningkatan konsumsi Jahe pada anak akan membatu menjaga imunitas anak.

\section{Kesimpulan}

Pengabdian masyarakat dengan diberikan penyuluhan 5 responden mempunyai pengetahuan baik sebelum penyuluhan dan 17 reponden mempunyai pengetahuan baik setelah penyuluhan. Pengabdian masyarakat dengan diberikan keterampilan 4 responden mempunyai keterampilan baik sebelum demonstrasi dan 21 reponden mempunyai keterampilan baik setelah demonstrasi.

\section{Daftar Pustaka}

Hartanti, D., Dhiani, B. A., Charisma, S. L., \& Wahyuningrum, R. (2020). The Potential Roles of Jamu for COVID-19: A Learn from the Traditional Chinese Medicine. Pharmaceutical Sciences \& Research, 74$), 2$.

https://health.kompas.com/read/2020/05/23/100000268/idai-tidak-benar-anak-tidak-rentanterhadap-covid-19?page=all

Lentera, T. (2002). Khasiat dan manfaat jahe merah si rimpang ajaib. AgroMedia.

RAHAYU, S. (2019). KAJIAN KARAKTERISTIK ORGANOLEPTIK MINUMAN TRADISIONAL DIPENGARUHI PERBANDINGAN KONSENTRASI EKSTRAK JAHE MERAH (Zingiber officinale var. Rubrum) DENGAN KOSENTRASI GULA AREN (Doctoral dissertation, Fakultas Teknik Unpas).

Saragih, B., \& Saragih, F. M. (2020). GAMBARAN KEBIASAAN MAKAN MASYARAKAT PADA MASA PANDEMI COVID-19.

Septiana, A. T., Muchtadi, D., \& Zakaria, F. R. (2002). AKTIVITAS ANTIOKSIDAN EKSTRAK DIKHLOROMETANA DAN AIR JAHE (Zingiber officinale Roscoe) PADA ASAM LINOLEAT [Antioxidant Activity of Ginger (Zingiber officinale Roscoe) Dichloromethane and Water Exctract on Linoleic Acid]. Jurnal Teknologi dan Industri Pangan, 13(2), 105-105.

Sunaryo, D. (2020). OPTIMALISASI PENDAPATAN MASYARAKAT DALAM PEMBUATAN PRODUK BANDREK JAHE SUSU SEBAGAI PENINGKATAN IMUNITAS DISAAT PANDEMIK COVID-19 
DI DESA SUKARATU KECAMATAN CIKEUSAL KABUPATEN SERANG. KOMMAS: Jurnal Pengabdian Kepada Masyarakat, 1(2).

Sutana, I. G., \& Dwipayana, A. P. (2020). Perilaku Konsumsi Jamu Covid-19. COVID-19: Perspektif Agama dan Kesehatan, 41.

Wulandari, S. (2018). Penggunaan Jahe Merah untuk Menurunkan Intensitas Nyeri Haid pada Remaja. VISIKES: Jurnal Kesehatan Masyarakat, 17(02). 